\title{
Review of "Education and Work"
}

\author{
Deborah P. Bloch \\ City University of New York
}

Poole, M. E. (Ed) (1992). Education and Work. Hawthorn, Victoria:

Australian Council for Educational Research. 246 pp.

Education and Work, a dynamic presentation of current issues facing schools in the post-modern era, consists of 11 essays by varied authors framed by two by the editor, Millicent Poole.

The essential elements of critical pedagogy are evident in Poole's first essay. She describes the "shifts in curriculum away from liberal education towards increased vocationalism" as "Policy perspectives on education and work [that] are not constructed in a sociocultural vacuum" (p. 1). Pointing to the growing strength of the New Right in forming the current curricular agenda for the schools she echoes Apple's idea that the political nature of education can be summed up not in Herbert Spencer's question of "'What knowledge is of most worth?"' but in the rephrasing "'Whose knowledge is of most worth?"' (Apple, 1991, p. 40). It is this underpinning of critical pedagogy - "the assumption that issues concerning curriculum, public schooling, and leadership cannot be discussed outside the language of power, politics, and struggle" Giroux, 1991, p. 14) - that supports each of the essays.

If Poole provides the skeleton in her opening and closing statements, two essays stand as the heart of this book. Blakers in "School to Work: Transition and Policy," clearly delineates the changes in the labour market that have led to greater insecurity for individuals, particularly since 1975. The chapter includes a fine analysis of recent trends in the labour market 
and related educational policy, making the telling point that society itself is in transition. This confounds the struggle of identifying how best to bring about the transition of young people from school to jobs. She concludes that, "Young people should not be seen merely as target groups - passive recipients of advice, services and welfare. They caul manage themselves, given opportunity and support and an education which helps each of them to develop fully and rigorously the capacities which make each one a valuable member of society" (p. 70). Stevenson and McKavanagh, in "Skill Formation in the Workplace," argue that the government definition of skill, which has been used as the basis for planning vocational education, is far too narrow. For example, internal processes such a "learning how to learn, discovery, analysis,..." (p. 77) have been ignored in favour of more easily observed and more easily acquired skills of performing specific tasks. Current developments in educational policy (if not practice) in the United States seem to be moving more in the direction of holistic, transition skills espoused by both these authors. The recent "SCANS Report" (Secretary's Commission on Achieving Necessary Skills, 1991) identifies five essential competencies: "identifies, organises, plans and allocates resources; works with others; acquires and uses information; understands complex inter-relationships; and works with a variety of technologies" (p. xvii). These appear similar to the "Key competency Strands" of the Mayer Committee Report (1992).

Essays by Butorac, "Socialisation to the World of Work: Analysis of Rural Children's Work Code," and by Evans and Poole, "Experiencing Work: Bridges to Adulthood," deal specifically with the acquisition of knowledge essential to a successful transition from student to worker. The Butorac chapter presents the author's ethnographic study of primary school children in a rural area. Evans and Poole examine a variety of work experiences of secondary and post-secondary students including schoolbased work experience, part-time work and working for a living. The two articles make clear the relationship between home, school and work experiences in shaping the self-development of individuals' attitudes and beliefs about work. These connections are further emphasised in three articles that concentrate on the these relationships as they affect women. Weeks examines the educational route for women into trades. Poole, Fox and Ciaveralla provide a review of the factors affecting career and family orientation of girls. And Sachs finds that sex discrimination is reinforced in schools.

The remaining articles continue the connection to the theme of education and work and to the philosophical links of critical pedagogy. Spaull provides a brief history of vocational education concentrating on the first decades of the twentieth century. Evers, in his philosophical perspective, argues for blurring of the distinction between liberal and vocational education" (p. 51). Davis utilises the Swedish and East Asia experiences to 
call for a policy that comprehensively unites education, households, and work. Finally, Lokan after reviewing the findings of the Work Importance Study, concludes that current educational policies may serve well those who are motivated and academically oriented but may not as successfully meet the needs of those with a more independent orientation to work, particularly students who may want to pursue entrepreneurial options. It may be noted that Herr (1992) has identified the set of entrepreneurial skills as critical to both individuals and nations as the shift from large corporations to smaller business organisations continues. Lokan ends by suggesting that for all students the development of life skills can best be accomplished through a general school reform in which students participate actively in the planning and assessment of their learning.

Poole's concluding essay provides both the context for improvement and concrete examples of how this may be done. She stresses curricular approaches that avoid the false dichotomy between general and vocational education and that incorporate the development of understanding of the relationship of oneself to work and society. She suggests career counselling approaches and practices that enable individuals to understand the changes in society and their roles throughout the life span. Finally, she advocates an educational philosophy that supports a "socially just and democratic society, with proper care given to community values and social relationship, and to the ethics of responsibility rather than just to self-interested economic instrumentalism" (p. 237).

The book has a number of strengths which pervade most, if not all, of the chapters. First, there is a consistency of point of view that informs each essay and that is, in turn, enlarged by the detail provided. Within the essays, there is ample information on the topic with specifics on labour market trends and changes, government policies as evidenced in law and reports, and educational programs. Each author contributes a depth of knowledge of her or his field. Finally, the essays combine to form a cohesive whole.

Despite the general strengths, there is room for improvement. On a minor note, three of the essays have a somewhat narrow focus and the reader must really stretch to make the leap from them to the conclusions of the book. Of greater disappointment was the lack of attention to ethnic or cultural diversity in the discussion. While the book calls for social justice for all, there is no research presented that deals with the relationships between education and work for recently arrived immigrants, for nonEuropean populations, or for aboriginal youth. There is also limited attention given to the need to enable all people to understand and work with those who are different from themselves.

The book is recommended for its understanding and presentation of critical issues facing Australia, the United States, and other post-industrial 
countries. It provides one more chorus of voices that can help us avoid panicking into repressive, narrowing choices of education focused on meeting immediate needs and teaching "basic skills." These choices are poor ones. First they limit the ability of individuals to find satisfaction in work. Second, when individual economic power is limited, the ability of nations to develop the resources needed for successful competition in the rapidly changing, global economy is similarly diminished.

\section{References}

Apple, M. W. (1991). The politics of curriculum and teaching. NASSP Bulletin, 75, 39-50.

Giroux, H. A. (1991). Curriculum planning, public schooling, and democratic struggle. NASSP Bulletin, 75, 12-25.

Herr, E. L. (1992). Counselling for personal flexibility in a global economy. Educational and Vocational Guidance: 40 Years Special Edition, 53, 5-16.

Mayer Committee. (1992). Employment-related key competencies: A proposal for consultation. Melbourne: The Mayer Committee.

Secretary's Commission on Achieving Necessary Skills. (1991). What work requires of schools: A SCANS Report for America 2000. Washington, DC: US Department of Labor.

Author: Dr Deborah Bloch is an Associate Professor in Career Education at the City University of New York. Her address is Department of Education, Baruch College, City University of New York.

Please cite as: Bloch, D. P. (1993). Review of "Education and Work". Australian Journal of Educational Technology, 9(1), 98-101. http: / / www.ascilite.org.au/ajet/ajet9/bloch.html 